Jurnal Akuntansi Indonesia, Vol. 9 No. 2 Juli 2020, Hal. 106 - 130

\title{
Faktor Keuangan dan Return on Asset Melalui Debt Equity Ratio
}

\author{
Dirvi Surya Abbas \\ Arry Eksandy \\ Mohmmad Zulman Hakim \\ Universitas Muhammadiyah Tangerang \\ Abbas.dirvi@gmail.com
}

\begin{abstract}
ABSTRAK
Maksud tujuan dari penelitian ini untuk mengetahui pengaruh yang ditimbulkan Rasio Lancar, Rasio PerputaranPiutang, Rasio Perputaran Persediaan, Rasio Perputaran Total Aset dan Rasio hutang terhadap ekuitas terhadap perbandingan Rasio laba atas aset. sampel yang digunakan adalah perusahaan 12 sub sektor otomotif dan komponen yang memenuhi kriteria dengan sebaran tahun 2011-2018. Metode pengambilan data dengan menggunakan metode purposive sampling. Data diperoleh dari laporan tahunan yang terdaftar di Bursa Efek Indonesia. Alat analisis yang digunakan dalam penelitian ini menggunakan analisis regresi linier berganda. Hasil penelitian ini menunjukkan bahwa Rasio Lancar dan Rasio Perputaran Total Aset berpengaruh positif signifikan terhadap Rasio laba atas aset. Variabel Rasio Perputaran Piutang dan Rasio hutang terhadap ekuitas berpengaruh negatif signifikan terhadap Rasio laba atas aset. Berdasarkan analisis jalur dan Sobel Test maka dapat disimpulkan bahwa Rasio hutang terhadap ekuitas hanya memediasi pengaruh Rasio Lancar terhadap Rasio laba atas aset.
\end{abstract}

Kata kunci: Faktor - Faktor Keuangan, Debt to Equity dan and Return on Asset.

\section{ABSTRACT}

The purpose of this study is to determine the effect of the Current Ratio, Debt Turnover Ratio, Inventory Turnover Ratio, Total Asset Turnover Ratio and Debt to Equity Ratio to the Ratio of Return on Assets. The sample used was 12 automotive sub-sector companies and components that met the criteria for the distribution of 2011-2018. The method of collecting data using purposive sampling method. Data is obtained from annual reports that are listed on the Indonesia Stock Exchange. The analytical tool used in this study uses multiple linear regression analysis. The results of this study indicate that the Current Ratio and Total Asset Turnover Ratio have a significant positive effect on the ratio of return on assets. Variable Accounts Receivable Ratio and Debt to Equity Ratios have a significant negative effect on the ratio of return on assets. Based on path analysis and the Sobel Test, it can be concluded that the debt to equity ratio only mediates the effect of the Current Ratio to the Ratio of return on assets.

Keywords: The Effect of Financial, Debt to Equity dan and Return on Asset. 


\section{PENDAHULUAN}

Dalam berinvestasi, investor biasanya akan menunjuk manajemen untuk melaksanakan tugasnya. Manajemen inilah yang aktif setiap hari menjalankan usaha. Manajemen akan berusaha memenuhi tujuan dari investor mendirikan perusahaan, selain itu perusahaan yang dikelolanya agar going concern. Menurut (Abbas 2017) dalam mengukur laba yang dihasilkan suatu perusahaan serta kinerja perusahaan dapat dilihat dari rasio profitabilitasnya hal tersebut tercermin didalam teori laporan keuangan. hal ini menegaskan bahwasanya bagi para investor dan kreditor dalam menginvestasikan hartanya haruslah melihat kemampulabaan perusahaan dan kinerja perusahaan yang dapat dilihat dari Rasio Profitabilitas.

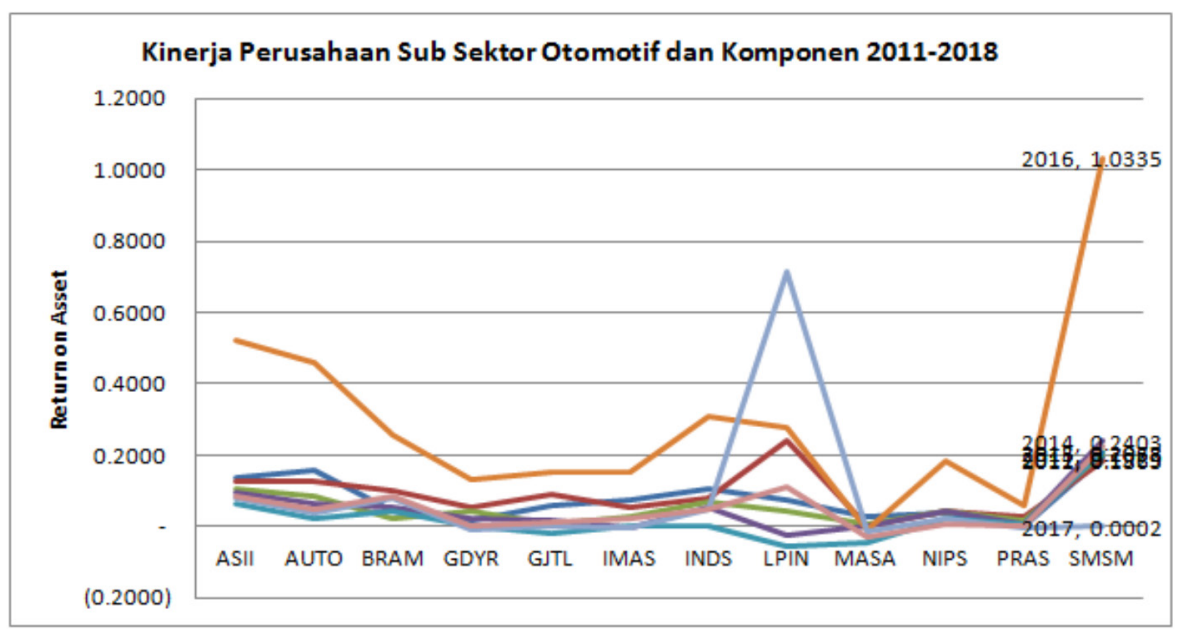

Gambar 1 Grafik Rasio Laba atas Aset

Perusahaan Sub Otomotif dan komponen (BEl; 2011-2018)

Berdasarkan grafik diatas, terlihat bahwa secara keseluruhan pergerakan Rasio Laba atas Aset pada beberapa Perusahaan yang di jadikan objek dalam penelitian ini dari tahun ke tahun mengalami dinamika kenaikan dan penurunan. Rasio Laba atas Aset pada Perusahaan tersebut mencapai dinamika kenaikan tertinggi pada tahun 2016 yakni sebesar 1,0335 dan pada tahun 2014 mencapai dinamika penurunan terendah, yaitu 0.0029. hal ini disebabkan peningkatan rata-rata total asetnya yang lebih tinggi dari laba setelah pajaknya. Dari grafik tersebut bisa disimpulkan bahwa Rasio Laba atas Aset bisa mengalami kenaikan atau bahkan penurunan yang signifikan.

Adapun hal - hal yang membuat terhambatnya kinerja Perusahaan tersebut, menurut (Nasution 2019) karena minimnya ketersediaan atasa bahan baku dalam menghasilkan komponen otomotif menjadi terkendala. Selain minimnya ketersediaan bahan baku, diduga harga yang ditawarkan kurang bersaing. selain itu, jika dilihat dari neraca perdagangan ekspor-impor barang komponen otomotif di Indonesia mengalami krisis. Pada tahun 2018, impor barang komponen otomotif mencapai 7,4 miliar dolar AS sedangkan ekspor hanya 7,2 miliar dolar AS sehingga terjadi kerugian sekitar 200 juta dolar AS. 
Rasio keuangan sangat populer dalam diskusi manajemen sehari-hari, terutama rasio profitabilitas. Profitabilitasmemang menjaditolakukurkeberhasilan manajemendalammenjalankanusahayang dipercayakan kepadanya. Oleh karena itu jenis rasio ini sangat sering ditemui dalam pembicaraan sehari-hari. Pada dasarnya rasio keuangan adalah perbandingan. Dari perbandingan pos-pos di laporan keuangan diharapkan muncul intepretasi tertentu. Terkait atas dengan penjelasan tersebeut maka hal tersebut dapat dijadikan alasan perihal beberapa dugaan yang dikembangkan atas rasio keuangan yang dapat mempengaruhi Rasio Laba atas Aset melalui Rasio Hutang terhadap ekuitas. Dugaan-dugaan tersebut diperkuat pula berdasarkan hasil penelitian yang dilakukan oleh para peneliti dalam membantu investor untuk menilai kinerja suatu perusahaan sehingga menjadi research gap dalam penelitian ini.

Rasio Profitabilitas dalam penelitian ini diproksikan dengan Rasio Laba atas Aset. Rasio ini adalah suatu kemampuan menghasilkan laba. dalam analisis rasio, kemampuan menghasilkan laba dapat dikaitkan dengan penjualan, aset dan modal. Pemilihan rasio tergantung dari mana kita akan melihat. Profitabilitas mendapat tempat tersendiri dalam penilaian perusahaan. Hal ini mudah dipahami karena secara sadar perusahaan didirikan memang untuk memperoleh laba.

Rasio Likuiditas dalam penelitian ini diproksikan dengan Rasio Lancar. Rasio ini bertujuan untuk mengengetahui sejauh mana kemampuan perusahaan dalam melunasi kewajiban jangka pendeknya. Oleh karena itu pos-pos yang dihitung adalah pos neraca pada bagian aset lancar dan hutang lancar.

Rasio aktivitas dalam penelitian ini diproksikan dengan Rasio Perputaran Piutang. Rasio Perputaran Persediaan dan Rasio Perputaran Total Aset merupakan suatu rasio aktivitas yang digunakan untuk mengukur tingkat efektivitas penggunaan aset perusahaan. Rasio ini sering juga disebut rasio perputaran atau turnover. Secara umum semakin tinggi perputaran berarti semakin efektif tingkat penggunaan aset perusahaan. Rasio ini terutama mengamati aset-aset yang dianggap penting bagi perusahaan. Aset yang dihitung biasanya dikaitkan dengan pendapatan.

Rasio Leverage dalam penelitian ini diproksikan dengan Rasio Hutang terhadap ekuitas. Rasio ini digunakan untuk mengukur kemampuan perusahaan untuk melunasi hutangnya. Hutang dapat dibandingkan dengan aset atau modal sendiri. Dapat juga dilihat kaitannya dengan bunga yang muncul dari utang dengan laba yang dihasilkan.semakin sedikit hutang yang dimiliki oleh perusahaan, maka akan semakin rendah resiko keuangan.

Bahwasanya penelitian ini mengkaitkan variabel mediasi didalamnya. Adapun variabel mediasi didalam penelitian ini adalah Rasio Hutang terhadap ekuitas. Diduga variabel ini mampu memediasi variabel eksogen dalam mempengaruhi profitabilitas baik secara langsung maupun tidak langsung. Menurut hasil penelitian yang dilakukan oleh (Mahardhika and Marbun 2016) menyatakan bahwa Rasio Hutang terhadap ekuitas positif terhadap Rasio Laba atas aset. Hal ini mengartikan bahwa semakin besar tingkat pinjaman yang dimiliki oleh perusahaan, sangat mempengaruhi tingkat kemampuan perusahaan dalam memperoleh labanya. Biasanya hal tersebut terjadi pada perusahaan yang baru berdiri atau berkembang. Namun berbeda dengan hasil penelitian yang dilakukan oleh (Abbas 2017) yang menyatakan bahwa Hutang terhadap ekuitas berpengaruh negatif terhadap Rasio Laba Atas Aset. Hal tersebut berarti menunjukkan bahwa hutang jangka panjang akan 
berbanding lurus dengan Profit. Hal ini dapat dilihat dari banyaknya perusahaan yang menggunakan sumber dana yang berasal dari kreditor perusahaan dibanding dana Investment. Selain Pinjaman yang didapat dalam jumlah yang besar, serta diikuti oleh waktu pengembaliannya yang juga lama (Flexible). Dengan kewajiban jangka panjang, perusahaan dapat melakukan ekspansi atau mengembangkan perusahaannya sehingga Profitabilitas yang didapat Perusahaan tentunya akan bertambah.

Selain kemampulabaan serta kinerja perusahaan yang menjadi faktor agar perusahaan bisa tetap going concern, ada faktor lain yang mempengaruhimya yakni Pengelolaan asset. karena maksimal atau tidaknya pengelolaan aset diperusahaan akan mempengaruhi manajemen dalam pengambilan suatu keputusan. Dengan kata lain, jika aset tidak dikelola dengan baik serta diikuti dengan adanya hutang yang besar dari jumlah aset yang ada, hal tersebut akan menyulitkan perusahaan dalam meningkatkan labanya secara maksimal.

\section{TELAAH LITERATUR DAN PENGEMBANGAN HIPOTESIS}

\section{Teori Profitabilitas}

Menurut (Brigham and Gapenski 1993) serangkaian kebijakan serta keputusan yang dapat dijadikan acuan perusahaan untuk menentukan strategi kedepan adalah Profitabilitas. Keadaan perusahaan dalam posisi profit merupakan cara agar perusahaan dapat menjaga kelangsungan hidupnya. Bagi perusahaan, salah satu cara agar mendapatkan sumber dana dari pihak eksternal adalah dengan cara menyakinkan serta membuktikan perusahaan yang dikelolanya dapat menghasilkan keuntungan atau laba. Petingnya akan kesadaran tentang keuntungan yang dihasilkan oleh perusahaan bagi Pemilik perusahaan dan pihak manajemen. Menjadi suatu alasan mengapa Pemilik perusahaan dan pihak manajemen akan selalu berusaha meningkatkan pencapaian kinerjanya agar dapat memaksimalkan keuntungan perusahaan.

\section{Profitabilitas}

Menurut (Mahardhika and Marbun 2016) Rasio profitabilitas harus dapat menggambarkan kemampuan perusahaan dalam menghasilkan laba melalui semua kegiatan operasional dan pemasaran dengan mengkaitkan dengan penjualan, aset dan modal yang dimiliki oleh perusahaan. dengan kata lain bahwa laba atas aset adalah tingkat pengembalian atas aset yang digambarkan melalui laba. profitabilitas mendapat tempat tersendiri dalam penilaian perusahaan. Hal ini dapat dipahami karena secara sadar perusahaan didirikan memang untuk memperoleh laba. Dalam penelitian ini rasio yang digunakan dalam mengukur profitabilitas adalah rasio laba atas aset (Return on Asset) adapun tujuan dari perhitungan rasio ini adalah untuk mengetahui seberapa besar aset yang digunakan dalam menghasilkan laba, dalam hal ini laba yang digunakan adalah EBIT (Earning Before Interest and Tax)..

\section{Likuiditas}

Menurut (Mahardhika and Marbun 2016) Rasio Lancar dari sisi manajemen, jika rasio kelancaran yang tinggi dianggap baik, karena kreditor melihat bahwasanya perusahaan dianggap memiliki kemampuan 
dalam melunasi kewajiban jangka pendeknya tanpa melakukan penjualan asetnya. Namun jika perusahaan memiliki rasio kelancaran yang tinggi tidak selamanya akan dianggap baik, karena hal tersebut bisa saja terjadi dikarenakan banyak tagihan piutang yang macet sehingga menyebabkan rasio kelancaran ini menjadi sangat tinggi. Konsep dari rasio lancar ini sangat mudah dipahami. Jika kita memiliki kewajiban yang segera harus dibayar, bukankah harus tersedia aset yang dengan mudah dapat digunakan untuk membayarnya. Dalam penelitian ini rasio yang digunakan dalam mengukur likuiditas adalah rasio Lancar (Current Ratio) adapun tujuan dari perhitungan rasio ini adalah untuk mengetahui sampai seberapa jauh sebenarnya jumlah aset lancar perusahaan dapat menjamin utang dari kreditor jangka pendek (vendor atau penyedia barang/ jasa).

\section{Aktivitas}

Menurut (Mahardhika and Marbun 2016) Rasio aktivitas digunakan untuk menggambarkan seberapa hemat penggunaan aset yang digunakan oleh perusahaan untuk mendapatkan perndapatan. Rasio aktivitas sering digunakan oleh manajemen untuk mengukur tingkat efektivitas penggunaan aset perusahaan. Rasio ini biasanya disebut sebagai rasio perputaran. Rasio ini menggambarkan semakin tinggi perputarannya berarti semakin efektif tingkat penggunaan aset-aset yang dianggap penting bagi perusahaan. Dalam penelitian ini rasio yang digunakan ada tiga rasio, yaitu yang pertama, rasio perputaran piutang usaha (Account Receivable Turnover). Rasio ini digunakan untuk mengukur seberapa cepat perusahaan dapat menagih piutangnya. Lalu, rasio perputaran persediaan, data yang digunakan dalam rasio ini adalah Harga pokok penjualan. Harga pokok penjualan tidak mengandung laba, begitu pula dengan persediaan tidak mengandung unsur laba. perputaran yang tinggi menunjukkan tingkat persediaan yang ada telah cukup baik, dalam pengertian adanya persediaan bukan sebagai akibat ketidakmampuan produk dalam bersaing dipasar. Dan yang terakhir adalah rasio perputaran total aset. Rasio ini digunakan untuk mengetahui tingkat efektifitas penggunaan aset operasi perusahaan dalam menghasilkan pendapatan. Apabila perusahaan menghasilkan pendapatan yang sama dengan aset lebih sedikit berarti perusahaan tersebut semakin efektif, karena memerlukan tingkat investasi yang lebih rendah.

\section{Leverage}

Menurut (Mahardhika and Marbun 2016) Rasio solvabilitas mengukur kemampuan perusahaan dalam memenuhi kewajiban jangka panjangnya atau lebih dari setahun. Biasanya hutang ini terkait akan peminjaman perusahaan untuk pernyertaan investasi (Pembelian aset). dengan kata lain rasio ini digunakan untuk menilai seberapa besar perusahaan memiliki hutang yang dibiayai oleh pihak lain terutama lembaga keuangan. Penggunaan utang yang terlalu tinggi akan berbahaya bagi sebuah perusahaan, apalagi jika total hutang melebihi total modal yang dimiliki perusahaan. Maka hal tersebut sudah dapat dikatakan perusahaan tersebut sedang mengalami kesulitan keuangan secara tidak langsung. Dalam penelitian ini rasio yang digunakan dalam mengukur leverage adalah rasio hutang terhadap ekuitas (Debt to Equity Ratio) adapun tujuan dari perhitungan rasio ini adalah untuk menunjukkan jumlah hutang sama dengan ekuitas. semakin tinggi rasio ini semakin tinggi resiko kebangkrutan perusahaan. 


\section{Pengembangan Hipotesis}

\section{Pengaruh Rasio Lancar terhadap Rasio Laba atas Aset.}

Rasio Lancar diduga memiliki pengaruh terhadap Rasio Laba atas Aset. Hal tersebut diperkuat oleh hasil penelitian yang dilakukan oleh (Abbas 2017) dan Rahmah, Cipta, \&Yudiaatmaja (2016) yang mengatakan bahwa bahwa Rasio Lancar berpengaruh positif terhadap Rasio Laba atas Aset. Hal tersebut menunjukkan bahwa kreditur akan mengetahui seberapa besar tingkat keamanan uang yang di investasikan pada perusahaan tersebut dengan melihat rasio lancarnya. Semakin baik rasio likuiditas ini maka keadaan perusahaan akan semakin likuid. Ini berarti perusahaan semakin mampu merespon kebutuhan sehari-harinya, sehingga tujuan utamanya untuk mendapatkan laba yang optimal dapat tercapai. Tentu hal tersebut akan berdampak pada profitabilitas perusahaan yang semakin meningkat.

\section{H1: Rasio Lancar berpengaruh terhadap Rasio Laba atas Aset.}

\section{Pengaruh Rasio Perputaran Piutang terhadap Rasio Laba atas Aset.}

Dugaan selanjutnya adalah Rasio Peputaran Piutang Usaha. Menurut hasil penelitian yang dilakukan oleh Suryadi, Taqwa \& Areva (2013) dan Nike et al (2014) menyatakan bahwa Rasio Peputaran Piutang Usaha berpengaruh positif terhadap Rasio Laba Atas Aset. Hal tersebut mengartikan bahwa semakin tepat waktu pelanggan dalam pelunasan piutangnya dengan batas waktu yang dijanjikan atas penjualan yang telah diberikan, dengan kata lain bahwa perusahaan telah memanajemen piutang usahanya dengan baik sehingga mampu menagih penjualan sesuai dengan komitmen yang telah ditentukan dan sehingga terhindar dari resiko adanya piutang tak tertagih dari Pelanggan. Namun berbeda dengan hasil penelitian yang dilakukan oleh Abbas (2018) yang menyatakan bahwa Rasio Peputaran Piutang Usaha berpengaruh negatif terhadap Rasio Laba Atas Aset. Hal tersebut menunjukkan bahwa semakin besar piutang yang tertanam diperusahaan lain akan berdampak pada menurunnya perputaran penerimaan kas perusahaan, sehingga perusahaan menjadi kekurangan modal dalam hal meningkatkan pengembalian asetnya.

\section{H2: Rasio Perputaran Piutang berpengaruh terhadap Rasio Laba atas Aset.}

\section{Pengaruh Rasio Perputaran Persediaan terhadap Rasio Laba atas Aset.}

Dugaan berikutnya, vaiabel Perputaran Persediaan. menurut hasil penelitian yang dilakukan oleh (Rahmawati 2012)Inventory Turnover, and Debt to Equity Ratio toward the Return on Assets (A Case Study of Listed Food and Beverage Company on the Indonesia Stock Exchange Years of 2007-2009 dan (Suryadi, Taqwa, and Areva 2012) menyatakan bahwa Perputaran Persediaan berpengaruh positif terhadap Rasio Laba atas Aset. Hal ini mengartikan bahwa rata-rata perputaran persediaan pada perusahaan cukup tinggi, yang menunjukkan bahwa semakin efesien waktu yang dibutuhkan perusahaan dalam menggunakan persediaan, maka semakin hemat biaya yang harus dikorbankan oleh perusahaan dalam hal biaya produktivitasnya. Dengan kata lain semakin efesien biaya yang harus digunakan perusahaan, maka hal tersebut akan meningkatkan laba perusahaan menjadi naik. Namun berbeda dengan hasil penelitian yang dilakukan oleh (Abbas 2017) yang menyatakan bahwa Rasio Peputaran Persediaan berpengaruh negatif terhadap Rasio Laba Atas Aset. Hal tersebut berarti menunjukkan bahwa volume penjualan yang tinggi pada perusahaan tersebut jika tidak 
dimbangi dengan pengelolaan aset persediaan yang baik akan menurunkan tingkat keefisiensian serta keefektifan perusahaan saat persediaan yang tinggi, dimana hal ini juga akan diikuti oleh meningkatkannya biaya-biaya yang terjadi selama pengelolaan persediaan berlangsung sehingga akan menurunkan pendapatan perusahaan.

\section{H3: Rasio Perputaran Persediaan berpengaruh terhadap Rasio Laba atas Aset.}

\section{Pengaruh Rasio Perputaran Total Aset terhadap Rasio Laba atas Aset.}

Lalu dugaan lainnya, Variabel Rasio Perputaran Total Aset. Menurut hasil penelitian yang dilakukan (Mahardhika and Marbun 2016), (Ambarwati, Yuniarta, and Sinarwati 2015), dan (Rahmah, Cipta, and Yudiaatmaja 2016) dan (Abbas 2017) menyatakan bahwa Total Asset Turnover berpengaruh positif terhadap Return On Assets. Hal tersebut berarti menunjukkan bahwa suatu perputaran Aset yang terjadi diperusahaan memiliki pengaruh yang signifikan dalam tingkat pengembalian aset perusahaan. Karena tingkat perputaran aset dapat meningkatkan penjualan pada perusahaan tersebut. Kondisi ini menunjukkan bahwa semakin tinggi nilai perputaran aset maka akan semakin besar tingkat penjualan, sehingga laba yang diterima perusahaan pun meningkat.

\section{H4: Rasio Perputaran Total Aset berpengaruh terhadap Rasio Laba atas Aset.}

\section{Pengaruh Rasio Hutang terhadap Ekuitas terhadap Rasio Laba atas Aset.}

Menurut hasil penelitian yang dilakukan oleh (Mahardhika and Marbun 2016) menyatakan bahwa Rasio Hutang terhadap Ekuitas positif terhadap Rasio Laba atas Aset. Hal ini mengartikan bahwa semakin besar tingkat pinjaman yang dimiliki oleh perusahaan, sangat mempengaruhi tingkat kemampuan perusahaan dalam memperoleh labanya. Namun, hasil penelitian tersebut bertolak belakang dengan dengan hasil penelitian yang dilakukan oleh (Rahmawati 2012)Inventory Turnover, and Debt to Equity Ratio toward the Return on Assets (A Case Study of Listed Food and Beverage Company on the Indonesia Stock Exchange Years of 2007-2009, dan (Rahmah, Cipta, and Yudiaatmaja 2016) didalam hasil penelitian mereka menyatakan bahwa Rasio Hutang terhadap Ekuitas berpengaruh Negatif terhadap Laba atas Aset.

\section{H5: Rasio Hutang terhadap Ekuitas berpengaruh terhadap Rasio Laba atas Aset.}

\section{Pengaruh Rasio Lancar terhadap Rasio Hutang terhadap Ekuitas.}

Berdasarkan hasil penelitian yang dilakukan (Hantono 2015) dalam penelitiannya menyatakan bahwa Rasio Lancar berpengaruh negative terhadap Debt to Equity. Hal ini mendefinisikan bahwa semakin rendah tingkat likuiditas suatu hutang lancer yang dimiliki oleh perusahaan, maka akan menurunkan manajemen untuk mengajukan pinjaman modal ke bank. sehingga hal tersebut mempengaruhi manajemen dalam meningkatkan kemampuan perusahaan dalam memperoleh untungnya.

\section{$\mathrm{H}_{6}$ : Rasio Lancar berpengaruh terhadap Rasio Hutang terhadap Ekuitas.}

\section{Pengaruh Rasio Perputaran Piutang Usaha terhadap Rasio Hutang terhadap Ekuitas}

Bahawasanya keterkaitan antara Rasio perputaran piutang dengan Rasio Hutang terhadap ekuitas 
tidaklah berkaitan. Karena jika Rasio perputaran piutang berbicara tentang pengelolaan piutang yang tertanam diperusahaan lain, lalu Rasio Hutang terhadap ekuitas berbicara tentang seberapa besar ekuitas yang dimiliki oleh perusahaan dalam menutupi hutang jangka panjangnya. Namun, jika diperhatikan lebih mendalam terdapatlah suatu keterkaitan antara perputaran piutang dengan Rasio Hutang terhadap ekuitas. Hal tersebut dapat terlihat dari semakin baiknya perputaran piutang yang dikelola oleh manajemen, maka hal tersebut akan mengurangi manajemen perusahaan untuk melakukan peminjaman modal kepada pihak ketiga. Sehingga jika pun tetap manajemen perusahaan melakukan pengajuan pinjaman kepada lembaga keuangan hal tersebut diduga tidak akan mengkhawatirkan pihak peminjam, diakarenakan manajemen perusahaan memiliki reputasi pengelolaan piutang usaha yang baik.

\section{$\mathbf{H}_{\mathbf{7}}$ : Rasio Perputaran Piutang Usaha berpengaruh terhadap Rasio Hutang terhadap Ekuitas.}

Pengaruh Rasio Perputaran Persediaan terhadap Rasio Hutang terhadap Ekuitas

Keterkaitan Perputaran Persediaan dengan Rasio Hutang terhadap ekuitas. Memiliki keterkaitan karena disatu sisi jika Perputaran Persediaan membahas akan ketersediaan barang yang akan dijual dengan dikaitkan dengan harga pokok penjualan nantinya. Dengan Rasio Hutang terhadap ekuitas sebagai sumber pendanaannya. Hal ini memberikan arti bahwa suatu cepatnya penjualan barang yang terjadi. maka, hal tersebut tidak akan membuat manajemen perusahaan untuk melakukan peminjaman kepada lembaga keuangan untuk menutupi ketidakmampuan produk perusahaan dalam berkompetisi dipasar. Hal tersebut mengartikan jika rata-rata perputaran persediaan pada perusahaan cukup tinggi, yang menunjukkan bahwa semakin efesien waktu yang dibutuhkan perusahaan dalam menggunakan persediaan, maka semakin hemat biaya yang harus dikorbankan oleh perusahaan dalam hal biaya produktivitasnya. Dengan kata lain semakin efesien biaya yang harus digunakan perusahaan, maka hal tersebut akan meningkatkan laba perusahaan menjadi naik, sehingga manajemen perusahaan tidak perlu melakukan pinjaman kepada lembaga keuangan untuk menutupi biaya-biaya operasional barang yang dijual karena ketidakmampuannya dalam berkompetisi.

$\mathrm{H}_{8}$ : Rasio Perputaran Persediaan berpengaruh terhadap Rasio Hutang terhadap Ekuitas.

\section{Pengaruh Rasio Perputaran Total Aset terhadap Rasio Hutang terhadap Ekuitas}

Bahwasanya rasio perputaran total aset digunakan untuk melihat kemampuan perputaran aset dalam menghasilkan pendapatan. Namun, terkadang diperusahaan sering ditemukan aset - aset yang dibeli oleh perusahaan terkadang tidak berkaitan dengan peningkatan perusahaan untuk menghasilkan pendapatan. Seperti pembelian mobil untuk direksi dsb. Sehingga hal tersebut terkadang membuat perusahaan mengalami kesulitas keuangan namun tidak mengalami kerugian. Dikarenakan untuk menutupi biaya - biaya perawatan atas aset yang tidak berkaitan untuk menunjang pendapatan perusahaan. Sehingga rasio hutang terhadap modal dapat berkaitan dengan Rasio perputaran total aset. Dengan situasi tersebut terkadang manejemen perusahaan akan mengajukan pinjaman ke lembaga keuangan untunk menutupi biay-biaya tersebut dan tidak mempengaruhi laba perusahaan. Dalam Hal ini pengertian Rasio perputaran total aset sesungguhnya mengartikan bahwa pendapatan yang didapatkan oleh perusahaan dapat dipengaruhi oleh 
fluktuatifnya tingkat penjualan di pangsa pasar tersebut. Jika penjualan barang yang menguntungkan dari perusahaan tersebut, selain perusahaan akan mendapatkan keuntungan yang sesuai, perusahasan dapat bisa mengalokasikan biaya perawatan aset yang setimpal, seperti aset yang terkait langsung untuk mendapatkan keuantungan perusahaan. Dengan begitu manajemen tidak akan melakukan pengajuan pinjaman kepada lembaga keuangan.

$\mathrm{H}_{9}$ : Rasio Perputaran Total Aset berpengaruh terhadap Rasio Hutang terhadap Ekuitas.

\section{METODE PENELITIAN}

\section{Populasi dan Sampel}

Dalam penelitian ini metode yang digunakan dalam pemilihan sampel adalah dengan meggunakan metode Purposive Sampling, pengertian puposive sampling yaitu tipe pemilihan sampel berdasarkan pertimbangan-pertimbangan tertentu dan pertimbangan yang diambil itu berdasarkan tujuan penelitian. Adapun populasi dalam penelitian ini adalah perusahaan Manufaktur subsektor Otomotif dan Komponen yang terdaftar di Bursa Efek Indonesia (BEI) dari tahun 2011-2018. Berdasarkan dari hasil pemilihan sample yang telah ditentukan kriterianya dengan menggunakan teknik purposive sampling, terpilihlah 12 sampel perusahaan dengan tahun pengamatan sebanyak 8 tahun atau sebanyak 96 data yang telah terkumpul.

\section{Variabel Eksogen}

Variabel eksogen adalah suatu variabel yang menjadi penyebab berubahnya atau yang menstimulan atas munculnya variabel endogen (Sugiyono 2017). Variabel eksogen dalam penelitian ini adalah suatu penyebab yang diduga memiliki keterkaitan Rasio Laba atas Aset yakni Rasio lancar, Rasio Perputaran Piutang Usaha, Rasio Perputaran Persediaan, Rasio Perputaran Total Aset, dan Rasio Hutang terhadap Ekuitas.

\section{Variabel Endogen}

Variabel Endogen adalah suatu variabel yang menjadi dampak atau eksistensinya distimulasi oleh adanya variabel eksogen (Sugiyono 2017). Variabel eksogen dalam penelitian ini adalah Rasio Laba atas Aset yang diukur dengan membandingkan Laba bersih dengan total aset. Rasio Laba atas Aset ini menggambarkan seberapa tinggi perusahaan dapat memperoleh laba atas seluruh sumber keuangan yang terdapat dari perusahaan.

\section{Variabel Intervenig}

Variabel Intervening atau variabel mediasi adalah suatu variabel yang secara fungsional menjadi perantara diantara pengaruh variabel eksogen terhadap variabel endogen (Listiyowati 2018). Variabel intervening dalam penelitian ini adalah Rasio Hutang terhadap Ekuitas.

\section{Metode Analisis}

Pengujian Hipotesis 
Metode Regresi Linier Berganda Penelitian ini menggunakan 2 (Dua) Persamaan untuk membahas masing - masing hipotesis adalah sebagai berikut :

\section{Hipotesis Model I}

$$
Y_{1}=\alpha+\beta_{1} \chi_{1}+\beta_{2} \chi_{2}+\beta_{3} \chi_{3}+\beta_{4} \chi_{4}+\varepsilon \ldots(1)
$$

Hipotesis Model II

$$
Y_{2}=\alpha+\beta_{5} \chi_{1}+\beta_{6} \chi_{2}+\beta_{7} \chi_{3}+\beta_{8} \chi_{4}+\varepsilon \ldots(2)
$$

\begin{tabular}{|c|c|}
\hline$Y_{1}$ & $=$ Rasio Laba Atas Aset \\
\hline$Y_{2}$ & $=$ Rasio Hutang terhadap Ekuitas \\
\hline a & $=$ konstanta \\
\hline$\beta 1,2,3,4,5 . .9$ & $=$ koefisien regresi variabel \\
\hline $\mathrm{X}_{1}$ & $=$ Rasio Lancar \\
\hline $\mathrm{X}_{2}$ & = Rasio Perputaran Piutang Usaha \\
\hline$X_{3}$ & $=$ Rasio Perputaran Persediaan \\
\hline$x$ & $=$ Rasio Perputaran Total Aset \\
\hline & $=$ Error \\
\hline
\end{tabular}

Keterangan:

Pengujian Uji Sobel

Pengujian ini dilakukan untuk melihat keterkaitan hubungan langsung dan tidak langsung antara variabel eksogen terhadap variabel endogen melalui variabel mediasi. Dalam melihat hasil dari perhitungan pengujian ini dilihat berdasarkan nilai Probabilitas berdasarkan kriteria ditabel 6 dalam pengujian hipotesis. Selain itu, untuk melihat tingkat signifikansi atas pengaruh secara tidak langsung, haruslah dilakukan uji dengan menggunakan Sobel Test, dengan rumus:

$$
Z=\frac{a b}{\sqrt{\left(b^{2} S E_{a}^{2}\right)+\left(a^{2} S E_{b}^{2}\right)}}
$$

$\mathrm{ab} \quad$ : koefisien direct effect $\mathrm{a}$ dan $\mathrm{b}$

$\mathrm{SEa}^{2} \& \mathrm{SEb}^{2} \quad$ :Standard error dari koefisien a dan $\mathrm{b}$ 
Standar yang digunakan dalam pengujian dalam menentukan bahwa variabel intervening dapat dikatakan layak untuk memediasi antara variabel ekosgen dengan variael endogen yakni berdasarkan apabila nilai Z memiliki nilai lebih besar dari 1.98. nilai 1.98 adalah angka yang bersumber dari tabel Z normal dengan memiliki taraf signifikansi 5\% (Hayes and Preacher 2004).

\section{Uji Asumsi Klasik}

Uji Normalitas

Untuk menguji apakah data yang diolah telah terdistribusi dengan normal ataukah tidak, maka dari itu, untuk mengetahuinya dilakukan uji Kolmogorov-Smirnov. Dengan kriteria, Jika nilai sig lebih besar dari 5\% maka dapat disimpulkan bahwa residual menyebar normal, dan jika nilai sig lebih kecil dari 5\% maka dapat disimpulkan bahwa residual menyebar tidak normal (Priyatno 2012).

\section{Uji Multikolineritas}

Pengujian data berikutnya adalah uji multikolinieritas. pengujian ini bertujuan untuk melihat apakah model regresi yang akan digunakan nantinya, terdapat suatu korelasi antar variable bebas atau tidak. Kriteria pengujian ini dengan melihat nilai tolerance dan variance factor (VIF). Jika nilai tolerance $>0,10$ dan VIF $<10$ maka menunjukkan tidak adanya multikolinearitas. Serta, sebaliknya jika tolerance $<0,10$ dan VIF $>10$ dapat diartikan terjadinya multikolinearitas (Ghozali 2013).

\section{Uji Autokorelasi}

Pengujian data yang ketiga adalah uji Autokorelasi. Pengujian ini adalah untuk melihat hubungan yang terjadi antara residual dari objek pengamatan satu dengan objek pengamatan yang lain. Suatu model regresi yang relevan seharusnya tidak mengalami gejala autokorelasi. Untuk mendeteksi terdapat atau tidaknya gejala autokorelasi, hal tersebut dapat dilihat dengan kriteria dari nilai Durbin-Watson (DW) yang nantinya akan dibandingkan dengan DW tabel (Basuki 2015)

\section{Uji Heterokedasitas}

Pengujian data yang terakhir adalah Uji heterokedastisitas. Penggujian ini bermaksud untuk melihat apakah dalam suatu model regresi terjadi keanekaragaman variance dari residual satu objek pengamatan ke objek pengamatan yang lainnya. Kemungkinan adanya tanda heteroskedasitas dapat dilakukan dengan melihat diagram scatterpplot, dimana sumbu ZPRED $(X)$ adalah residual dan sumbu SRESID $(Y)$ adalah nilai $Y$ yang diprediksi (Priyatno 2012). Pengambilan keputusannya dengan kriteria Jika tidak terdapat pola tertentu, seperti titik-titik yang ada menyebar di atas serta dibawah batas 0 (sumbu Y) dan tidak teratur maka dapat dikatakan tidak terjadi heteroskedastisitas. Namun sebaliknya, jika terdapat pola tertentu, seperti titik-titik yang ada membentuk suatu pola tertentu yang teratur maka terjadi heteroskedastisitas. 


\section{HASIL DAN PEMBAHASAN}

\section{Hasil Analisis Deskriptif}

Tabel 2 Analisis Deskriptif

Descriptive Statistics

\begin{tabular}{|l|r|r|r|r|r|}
\hline & \multicolumn{1}{|c|}{$N$} & Minimum & Maximum & Mean & Std. Deviation \\
\hline Current Ratio & 96 & .48 & 7.92 & 1.8657 & 1.35880 \\
Debt to Equity & 96 & .10 & 8.26 & 1.1093 & 1.02506 \\
Receivable Turn Over & 96 & .00 & 16.97 & 4.1630 & 2.54182 \\
Inventory Turn Over & 96 & .00 & 11.29 & 4.3632 & 2.32712 \\
Total Aset Turn Over & 96 & .01 & 2.51 & .8153 & .41868 \\
Return on Asset & 96 & .13 & .72 & .0548 & .09421 \\
Valid N (listwise) & 96 & & & & \\
\hline
\end{tabular}

Dari tabel tersebut dapat terlihat bahwasanya nilai Rasio Lancar terendah yaitu sebesar 0.48 , dimiliki oleh PT Multistrada Arah Sarana Tbk pada tahun 2011. sedangkan, Rasio Lancar tertinggi yaitu sebesar 7.92 dimiliki oleh PT Indospring Tbk pada tahun 2016. Berdasarkan tabel diatas terlihat bahwa Rata-rata nilai Rasio Lancar selama periode pengamatan 2011-2018 adalah sebesar 1.8657. dengan nilai standar deviasi dari variabel Rasio Lancar adalah sebesar 1.35880 .

Intepretasi selanjutnya dapat terlihat bahwasanya nilai Perputaran Piutang Usaha terendah yaitu sebesar 0.00 dimiliki oleh PT Selamat Sempurna Tbk pada tahun 2014. Sedangkan, Nilai Perputaran Piutang Usaha tertinggi yaitu sebesar 16.97, dimiliki oleh PT Goodyear Indonesia Tbk pada tahun 2016. Berdasarkan tabel diatas terlihat bahwa nilai Rata-rata atas Perputaran Piutang Usaha selama periode pengamatan 2011-2018 adalah sebesar 4.1630 dengan nilai standar deviasi atas variabel Perputaran Piutang Usaha adalah sebesar 2.54182 .

Intepretasi selanjutnya dapat terlihat bahwasanya nilai Perputaran Persediaan terendah yaitu sebesar 0.00, dimiliki oleh PT Multi Prima Sejahtera Tbk. sedangkan, Nilai Perputaran Persediaan tertinggi yaitu sebesar 11.29 dimilki oleh PT Astra International Tbk. Berdasarkan tabel diatas terlihat bahwa Rata-rata nilai Perputaran Persediaan selama periode pengamatan 2011-2018 adalah sebesar 4.3632. dengan nilai standar deviasi dari variabel Perputaran Persediaan adalah sebesar 2.32712.

Intepretasi selanjutnya dapat terlihat bahwasanya nilai Perputaran Total Aset terendah yaitu 0.01, dimiliki oleh PT Goodyear Indonesia Tbk pada tahun 2017. Sedangkan, Nilai Perputaran Total Aset tertinggi yaitu sebesar 2.51, dimiliki oleh PT Goodyear Indonesia Tbk pada tahun 2016. Berdasarkan tabel diatas terlihat bahwa Rata-rata nilai Perputaran Total Aset selama periode pengamatan 2011 - 2018 adalah sebesar 0.8153. dengan nilai standar deviasi dari variabel Perputaran Total Aset adalah sebesar 0.41868 .

Intepretasi selanjutnya dapat terlihat bahwasanya nilai Hutang terhadap Ekuitas terendah yaitu 0.10, 
dimiliki oleh PT Goodyear Indonesia Tbk pada tahun 2013. Sedangkan, Nilai Hutang terhadap Ekuitas tertinggi yaitu sebesar 8.26, dimiliki oleh PT Indomobil Sukses Internasional Tbk pada tahun 2016. Berdasarkan tabel diatas terlihat bahwa Rata-rata nilai Hutang terhadap Ekuitas selama periode pengamatan 2011-2018 adalah 1.1093 dengan nilai standar deviasi dari variabel Hutang terhadap Ekuitas adalah sebesar 1.02506.

Intepretasi selanjutnya dapat terlihat bahwasanya nilai Laba atas Aset terendah yaitu -0.13 , dimiliki oleh PT Multi Prima Sejahtera Tbk pada tahun 2014. Sedangkan, Nilai Laba atas Aset tertinggi yaitu sebesar 0.72, dimiliki oleh PT Selamat Sempurna Tbk pada tahun 2016. Berdasarkan tabel diatas terlihat bahwa Rata-rata nilai Laba atas Aset selama periode pengamatan 2011-2018 adalah 0.0548. dengan nilai standar deviasi dari variabel Laba atas Aset adalah sebesar 0.09421

Hasil Uji Normalitas

Tabel 3 Hasil Uji Normalitas

\begin{tabular}{|ll|r|}
\hline \multicolumn{3}{|c|}{ One-Sample Kolmogorow-Smirnow Test } \\
\hline N & $\begin{array}{c}\text { Unstandardiz } \\
\text { ed Predicted } \\
\text { Value }\end{array}$ \\
\hline Normal Parameters= & Mean & 96 \\
Most Extreme Differences & .0547917 \\
& Std. Deviation & .05576267 \\
Kolmogorow-Smirnow $Z$ & Positive & .076 \\
Asymp. Sig. (2-tailed) & Negative & .054 \\
\hline \multicolumn{2}{|c|}{} & -.076 \\
& & .747 \\
\hline
\end{tabular}

a. Test distribution is Normal.

Berdasarkan diatas didapatkan hasil atas pengujian normalitas dengan metode One-Sample KS Test, didapatkan nilai Asymp. Sig (2-Tailed) sebesar 0.632 yang mengartikan bahwa data dalam penelitian ini telah terdistribusi dengan normal karena kriteria standar lebih besar dari 0.05 .

\section{Hasil Uji Multikolineritas}

Tabel 4 Hasil Uji Multikolineritas

\begin{tabular}{llll}
\hline \multicolumn{2}{c}{$\begin{array}{c}\text { Model } \\
\text { Tolerance }\end{array}$} & \multicolumn{2}{c}{ Collinearity Statistics } \\
\cline { 3 - 4 } & (Constant) & \multicolumn{2}{c}{ VIF } \\
\hline \multirow{2}{*}{$1 \quad$ Current Ratio } & .778 & 1.286 \\
\cline { 2 - 4 } & Debt to Equity & .901 & 1.110 \\
& Receivable Turn Over & .885 & 1.130 \\
& Inventory Turn Over & .831 & 1.203 \\
& Total Aset Turn Over & .801 & 1.248 \\
\hline
\end{tabular}

a. Dependent Variable: Return on Asset 
Berdasarkan tabel diatas, terlihat bahwa hasil dari pengujian multikolinearitas rata-rata berada dibawah nilai tolerance. Dapat diartikan bahwa kelima variabel bebas dalam penelitian ini lolos uji multikolinearitas. Dengan kriteria standar kelolosan setiap variabel harus memiliki nilai lebih besar dari $>0,10$ dengan nilai VIF kurang dari $<10$. sehingga dapat dikatakan bahwa variabel yang independen dalam penelitian ini tidak mengalami gejala multikolinearitas.

\section{Uji Heteroskedastisitas}

\section{Scatterplot}

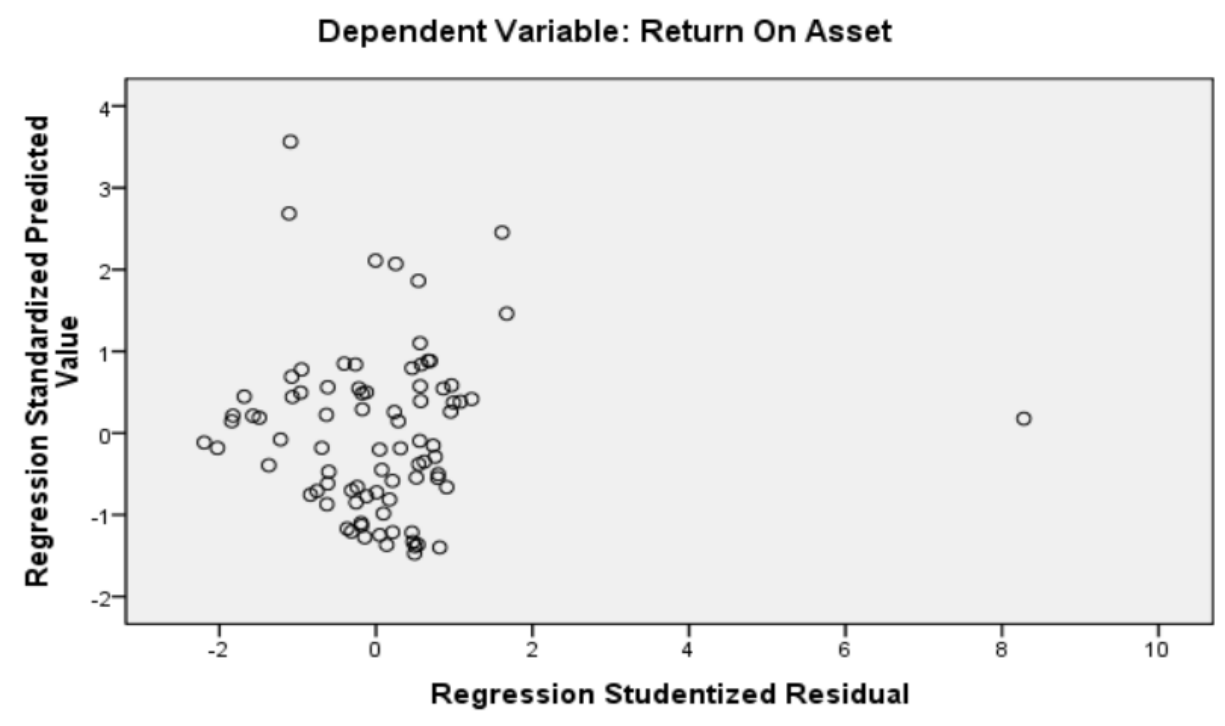

Gambar 2 Uji Heteroskedastisitas

Berdasarkan gambar diatas menunjukkan data (titik-titik) menyebar secara merata di atas dan di bawah garis nol. Dengan begitu bahwa hasil tersebut dapat menggambarkan bahwa tidak terjadi gejala heteroskedastisitas dalam model regresi yang akan digunakan dalam penelitian ini.

\section{Hasil Uji Autokorelasi}

Tabel 5 Hasil Uji Autokorelasi

\begin{tabular}{|c|c|}
\hline Model & Durbin-Watson \\
\hline 1 & 1,718 \\
\hline
\end{tabular}

Tabel 5 menunjukkan bahwa nilai Durbin-Watson adalah sebesar 1,718. Nilai batas atas (dL) pada tabel Durbin-Watson dengan signifikansi 5\% dan jumlah sampel 96 dengan $(k=5)$ memiliki nilai 1.5600. Nilai pada batas bawah (dU) memiliki nilai 1.7785 Karena nilai DW 1.718 lebih kecil dari batas atas (dU) 1.7785 dan lebih 
besar dari dL (1.5600), maka dapat disimpulkan bahwa tidak terdapat autokorelasi positf atau negatif.

\section{Hasil Uji Hipotesis}

Tabel 6 Hasil Uji Hipotesis

\begin{tabular}{|c|c|c|c|c|c|c|}
\hline Uraian & Standarized Beta & SE & $\mathbf{T}$ & Unstandarized Beta & Sig. & Keterangan \\
\hline \multicolumn{7}{|c|}{ Model Hipotesis I: $Y_{1}=\alpha+\beta 1 X_{1}+\beta 2 X_{2}+\beta 3 X_{3}+\beta 4 X_{4}+\beta 5 Y_{2}+\varepsilon$} \\
\hline \multirow[t]{3}{*}{ ROA« Current ratio } & \multirow{2}{*}{\multicolumn{2}{|c|}{0.314}} & & & & \\
\hline & & & 3.257 & 0.022 & 0.022 & Signifikan \\
\hline & \multicolumn{2}{|l|}{0.007} & & & & \\
\hline ROA «Acc Receive Tr & -0.239 & 0.003 & -2.670 & -0.009 & 0.009 & Signifikan \\
\hline ROA «Inv Turnover & 0.066 & 0.004 & 0.735 & 0.003 & 0.464 & Tidak Signifikan \\
\hline ROA «Total Asset Tr & 0.324 & 0.021 & 3.479 & 0.073 & 0.001 & Signifikan \\
\hline $\mathrm{ROA}$ «DER & -0.222 & 0.009 & -2.339 & -0.020 & 0.022 & Signifikan \\
\hline \multicolumn{7}{|c|}{ Model Hipotesis II : Y2 $=\alpha+\beta 6 X 1+\beta 7 X 2+\beta 8 X 3+\beta 9 X 4+\varepsilon$} \\
\hline DER «Current ratio & -0.420 & 0.073 & -4.334 & -0.317 & 0.000 & Signifikan \\
\hline DER « Acc Receive Tr & -0.063 & 0.040 & -0.640 & -0.025 & 0.524 & Tidak Signifikan \\
\hline DER «Inv Turnover & -0.063 & 0.044 & -0.633 & -0.028 & 0.528 & Tidak Signifikan \\
\hline DER «Total Asset Tr & -0.094 & 0.251 & -0.922 & -0.231 & 0.359 & Tidak Signifikan \\
\hline \multicolumn{4}{|c|}{ Z Score (CR --> DER --> ROA) } & \multicolumn{3}{|c|}{1.99} \\
\hline \multicolumn{4}{|c|}{ Z Score (Acc Receive Tr --> DER --> ROA) } & \multicolumn{3}{|c|}{1.79} \\
\hline \multicolumn{4}{|c|}{ Z Score (Inv Turnover --> DER --> ROA) } & \multicolumn{3}{|c|}{-0.71} \\
\hline \multicolumn{4}{|c|}{ Z Score (Total Asset Tr --> DER --> ROA) } & \multicolumn{3}{|c|}{-1.87} \\
\hline
\end{tabular}

Keterangan : $\quad * *$ adalah signifikansi $\leq 0.05$

$Z_{\text {score }}>1,98$. Standar variabel intervening mampu memediasi variabel lainnya.

$\mathrm{SE}=$ Standard Eror

Hasil Pengujian Model Hipotesis Tipe I

$$
\gamma_{1}=a+\beta_{1} x_{1}+\beta_{2} x_{2}+\beta_{3} x_{3}+\beta_{4} x_{4}+\varepsilon
$$

Return On Asset $=0.003+0.022 X_{1}-0.009 X_{2}+0.003 X_{3}+0.073 X_{4}-0.020 Y_{2}+\varepsilon$

Hasil Pengujian Model Hipotesis Tipe II

$$
v_{2}=a+\beta_{5} x_{1}+\beta_{6} x_{2}+\beta_{7} x_{3}+\beta_{8} x_{4}+\varepsilon
$$

Debt Equity Ratio $=2.116-0.317 X_{1}-0.025 X_{2}-0.028 X_{3}-0.231 X_{4}+\varepsilon$

Berdasarkan hasil persamaan diatas didapatkan penjelasan sebagai berikut:

a. Terlihat bahwa nilai konstanta dalam Persamaan regresi diatas adalah sebesar 0,003. Dengan kata lain dapat diartikan apabila variabel Eksogen yaitu Rasio Lancar, Rasio Perputaran Piutang Usaha, Rasio Perputaran Persediaan, Rasio Perputaran Total Aset dan Rasio Hutang terhadap Ekuitas konstan maka 
nilai Rasio Laba atas Aset yakni 0,003.

b. Terlihat bahwa nilai Koefisien $\beta 1$ yaitu Rasio Lancar $\left(X_{1}\right)$ dalam Persamaan regresi diatas didapatkan hasil sebesar 0.022. hal tersebut mempunyai arti bahwa jika variabel Rasio Lancar meningkat 1 satuan dan variabel Rasio Perputaran Piutang Usaha $\left(\mathrm{X}_{2}\right)$, Rasio Perputaran Persediaan $\left(\mathrm{X}_{3}\right)$, Rasio Perputaran Total Aset $\left(\mathrm{X}_{4}\right)$ dan Rasio Hutang terhadap Ekuitas $\left(\mathrm{Y}_{2}\right)$ tetap, maka nilai variabel Rasio Laba atas Aset $\left(\mathrm{Y}_{1}\right)$ akan naik sebesar 0.022 .

c. Terlihat bahwa nilai Koefisien regresi $\beta 2$ yaitu Rasio Perputaran Piutang Usaha $\left(\mathrm{X}_{2}\right)$ dalam Persamaan regresi diatas didapatkan hasil sebesar -0.009. hal tersebut mempunyai arti bahwa jika variabel Rasio Perputaran Piutang Usaha $\left(\mathrm{X}_{2}\right)$ menurun 1 satuan dan variabel Rasio Lancar $\left(\mathrm{X}_{1}\right)$, Rasio Perputaran Persediaan $\left(\mathrm{X}_{3}\right)$, Rasio Perputaran Total Aset $\left(\mathrm{X}_{4}\right)$ dan Rasio Hutang terhadap Ekuitas $\left(\mathrm{Y}_{2}\right)$ tetap, maka nilai variabel Rasio Laba atas Aset $\left(\mathrm{Y}_{1}\right)$ akan turun sebesar -0.009.

d. Terlihat bahwa nilai Koefisien regresi $\beta 3$ yaitu Rasio Perputaran Persediaan $\left(\mathrm{X}_{3}\right)$ dalam Persamaan regresi diatas didapatkan hasil sebesar 0.003. hal tersebut mempunyai arti jika variabel Rasio Perputaran Persediaan $\left(\mathrm{X}_{3}\right)$ meningkat 1 satuan dan variabel Rasio Lancar $\left(\mathrm{X}_{1}\right)$, Rasio Perputaran Piutang Usaha $\left(\mathrm{X}_{2}\right)$, Rasio Perputaran Total Aset $\left(\mathrm{X}_{4}\right)$ dan Rasio Hutang terhadap Ekuitas $\left(\mathrm{Y}_{2}\right)$ tetap, maka nilai variabel Rasio Laba atas Aset $\left(Y_{1}\right)$ akan naik sebesar 0.003 .

e. Terlihat bahwa nilai Koefisien regresi $\beta 4$ yaitu Rasio Perputaran Total Aset $\left(\mathrm{X}_{4}\right)$ dalam Persamaan regresi diatas didapatkan hasil sebesar 0.073. hal tersebut mempunyai arti jika variabel Perputaran Total Aset meningkat 1 satuan dan Rasio Lancar $\left(\mathrm{X}_{1}\right)$, Rasio Perputaran Piutang Usaha $\left(\mathrm{X}_{2}\right)$, Rasio Perputaran Persediaan $\left(\mathrm{X}_{3}\right)$, dan Rasio Hutang terhadap Ekuitas $\left(\mathrm{Y}_{2}\right)$ tetap, maka nilai variabel Rasio Laba atas Aset $\left(\mathrm{Y}_{1}\right)$ akan naik sebesar 0.073 .

f. Terlihat bahwa nilai Koefisien regresi $\beta 5$ yaitu Rasio Hutang terhadap Ekuitas $\left(\mathrm{Y}_{2}\right)$ dalam Persamaan regresi diatas didapatkan hasil sebesar -0.020. hal tersebut mempunyai arti jika variabel Rasio Laba atas Aset menurun 1 satuan dan variabel Rasio Lancar (X1), Rasio Perputaran Piutang Usaha (X2), Rasio Perputaran Persediaan (X3), dan Rasio Perputaran Total Aset (X4) tetap, maka nilai variabel Rasio Laba atas Aset (Y1) akan turun sebesar 0.020 .

g. Terlihat bahwa nilai Koefisien regresi $\beta 6$ yaitu Rasio Lancar $\left(X_{1}\right)$ dalam Persamaan regresi diatas didapatkan hasil sebesar -0.317. hal tersebut mempunyai arti jika variabel Rasio Lancar $\left(\mathrm{X}_{1}\right)$ menurun 1 satuan dan variabel Rasio Perputaran Piutang Usaha $\left(\mathrm{X}_{2}\right)$, Rasio Perputaran Persediaan $\left(\mathrm{X}_{3}\right)$, dan Rasio Perputaran Total Aset $\left(\mathrm{X}_{4}\right)$ tetap, maka nilai variabel Rasio Hutang terhadap Ekuitas $\left(\mathrm{Y}_{2}\right)$ akan turun sebesar 0.317.

h. Terlihat bahwa nilai Koefisien regresi $\beta 7$ yaitu Rasio Perputaran Piutang Usaha $\left(\mathrm{X}_{2}\right)$ dalam Persamaan regresi diatas didapatkan hasil sebesar -0.025, hal tersebut mempunyai arti jika variabel Rasio Perputaran Piutang Usaha $\left(\mathrm{X}_{2}\right)$ menurun 1 satuan dan variabel Rasio Lancar $\left(\mathrm{X}_{1}\right)$, Rasio Perputaran Persediaan $\left(\mathrm{X}_{3}\right)$, dan Rasio Perputaran Total Aset $\left(\mathrm{X}_{4}\right)$ tetap maka nilai variabel Rasio Hutang terhadap Ekuitas $\left(\mathrm{Y}_{2}\right)$ akan turun sebesar 0.025 .

i. Terlihat bahwa nilai Koefisien regresi $\beta 8$ yaitu Rasio Perputaran Persediaan $\left(\mathrm{X}_{3}\right)$ dalam Persamaan regresi diatas didapatkan hasil sebesar -0.028 , hal tersebut mempunyai arti jika variabel Rasio Perputaran 
Persediaan $\left(\mathrm{X}_{3}\right)$ menurun 1 satuan dan variabel Rasio Lancar $\left(\mathrm{X}_{1}\right)$, Rasio Perputaran Piutang Usaha $\left(\mathrm{X}_{2}\right)$, dan Rasio Perputaran Total Aset $\left(\mathrm{X}_{4}\right)$, tetap maka nilai variabel Rasio Hutang terhadap Ekuitas $\left(\mathrm{Y}_{2}\right)$ akan turun sebesar 0.028 .

j. $\quad$ Terlihat bahwa nilai Koefisien regresi $\beta 9$ yaitu Perputaran Total Aset $\left(\mathrm{X}_{4}\right)$ dalam Persamaan regresi diatas didapatkan hasil sebesar -0.231, hal tersebut mempunyai arti jika variabel Rasio Perputaran Total Aset $\left(\mathrm{X}_{4}\right)$ menurun 1 satuan dan variabel Rasio Lancar $\left(\mathrm{X}_{1}\right)$, Rasio Perputaran Piutang Usaha $\left(\mathrm{X}_{2}\right)$, dan Rasio Perputaran Persediaan $\left(\mathrm{X}_{3}\right)$, tetap maka nilai variabel Rasio Hutang terhadap Ekuitas akan turun sebesar 0.231 .

\section{Uji t (Persamaan 1 dan 2)}

Berdasarkan hasil pengujian data yang dilakukan dengan menggunakan metode regresi linier berganda berbantuan software SPSS Versi 22, dengan standar tingkat penerimaan signifikansi yang digunakan adalah sebesar $5 \%$.

Berdasarkan hasil pengujian dalam regresi model tipe 1, menunjukkan bahwa variabel Rasio Perputaran Persediaan tidak memiliki pengaruh terhadap Rasio Laba atas Aset. Namun, variabel eksogen lainnya berpengaruh terhadap variabel endogen. tidak pengaruhnya Rasio Perputaran Persediaan tersebut dapat terlihat berdasarkan hasil nilai t-hitung yang berada dibawah nilai t-tabel. Adapun nilai t-tabel yang digunakan yakni sebesar 1.66159 dan nilai t-hitung pada variabel Rasio Perputaran Persediaan adalah sebesar 0.735.

selain berdasarkan dari nilai t-hitung, dalam menentukan tingkat pengaruhnya suatu variabel dapat pula dilihat berdasarkan dari taraf nilai signifikansinya. Adapun variabel eksogen yang memiliki standar nilai dibawah 5\% dalam model regresi tipe I ini yaitu Rasio Lancar sebesar 0.002, Rasio Perputaran Piutang sebesar 0.009, Rasio Perputaran Total Aset sebesar 0.001 dan Rasio Hutang terhadap Ekuitas sebesar 0.022.

selain itu, Hasil pengujian pada model regresi tipe II terlihat pada tabel diatas. Data menunjukkan bahwa variabel Rasio Perputaran Piutang Usaha, Rasio Perputaran Persediaan, Rasio Perputaran Total Aset tidak berpengaruh terhadap Rasio Hutang terhadap Ekuitas. Adapun nilai t-tabel dalam model regresi tipe II adalah sebesar 1.66159. adapun nilai t-hitung pada Rasio Perputaran Piutang Usaha adalah sebesar -0.640, Rasio Perputaran Persediaan sebesar -0.633, Rasio Perputaran Total Aset sebesar -0.922. selain berdasarkan dari nilai t-hitungnya, tingkat validitasnya suatu variabel eksogen, bisa dilihat dari taraf nilai signifikansinya. Adapun variabel yang memiliki nilai dibawah $5 \%$ yaitu hanya variabel Rasio Lancar saja yakni sebesar 0.000 .

\section{Sobel Test}

Kemampuan variabel intervening dalam memediasi ditentukan berdasarkan standar yang digunakan yakni apabila jika nilai Z > 1.98. berdasarkan hasil pengujian diatas menunjukkan bahwa Rasio Hutang terhadap Ekuitas mampu memediasi Rasio Lancar terhadap Rasio Laba atas Aset dengan kriteria 1.99 > 1.98. Lalu, Kemudian Z Score sebesar 1.79 menunjukkan bahwa Rasio Hutang terhadap Ekuitas tidak dapat memediasi Rasio Perputaran Piutang Usaha terhadap Rasio Laba atas Aset. Selanjutnya, Z Score sebesar -0.71 menunjukkan bahwa Rasio Hutang terhadap Ekuitas tidak dapat memediasi Rasio Perputaran Persediaan berpengaruh terhadap Rasio Laba atas Aset. Dan terakhir, Z 
Score sebesar -1.87 menunjukkan bahwa Rasio Hutang terhadap Ekuitas tidak dapat memediasi Rasio Perputaran Total Aset berpengaruh terhadap Rasio Laba atas Aset.

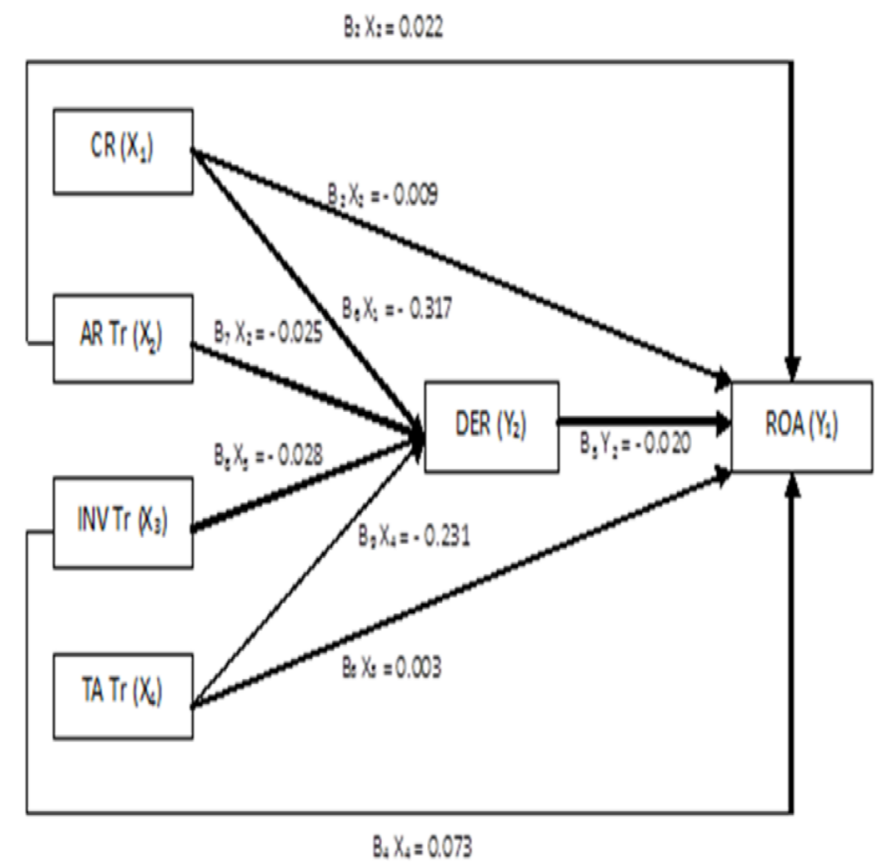

Gambar 2 Model Analisis Jalur

\section{Uji Koefisien Determinasi}

Tabel 7 Hasil Uji Koefisien Determinasi

\begin{tabular}{lrrrr}
\hline Model & $\mathrm{R}$ & $\begin{array}{c}\mathrm{R} \\
\text { Square }\end{array}$ & $\begin{array}{c}\text { Adjusted } \mathrm{R} \\
\text { Square }\end{array}$ & Std. Error of the Estimate \\
\hline 1 & $.446^{\mathrm{a}}$ & .199 & .163 & 0.93755 \\
\hline
\end{tabular}

Berdasarkan hasil tabel diatas, nilai adjusted $\mathrm{R}^{2}$ adalah sebesar 0,199 atau 19.9\%, hal tersebut mengartikan bahwa 19.9\% variabel Rasio Laba atas Aset dapat dijelaskan oleh kelima variabel eksogen yaitu Rasio Lancar, Rasio Perputaran Piutang Usaha, Rasio Perputaran Persediaan, Rasio Perputaran Total Aset dan Rasio Hutang terhadap Ekuitas.

Sedangkan sisanya yakni $80.10 \%$ dijelaskan oleh faktor lain, yang tidak termasuk kedalam model regresi penelitian ini. Lalu, Standar error of estimate (SEE) sebesar 0,93755. Menunjukkan bahwa jika nilai tersebut semakin rendah, maka model regresi yang diprediksi akan semakin tepat dalam menjelaskan variabel endogen yang diteliti. Berikut adalah penjelasan dari hasil pengujian berdasarkan hipotesa yang diangkat dalam penelitian ini. 


\section{Pengaruh Rasio Lancar terhadap Rasio Laba atas Aset.}

Berdasarkan hasil uji persamaan model 1 seperti didalam Tabel 6 terlihat bahwa nilai coefficient variabel dari Rasio Lancar memiliki pengaruh positif sebesar 0.022 terhadap Rasio Laba atas Aset. Pengaruh Rasio Lancar memiliki nilai siginifikan jika seseuai kriteria statistik karena didapatkan besaran nilainya yakni sebesar 0.022 lebih kecil dari 0.05, sehingga Hipotesa 1 dapat diterima. dengan demikian berarti, terdapat pengaruh dari variabel Rasio Lancar terhadap Rasio Laba atas Aset perusahaan manufaktur subsektor Otomotif dan Komponen yang terdaftar di Bursa Efek Indonesia (BEI) dari tahun 2011-2018.

Hasil pengujian ini sejalan dengan dugaan hipotesis diawal yakni rasio Lancar diduga memiliki pengaruh terhadap Rasio Laba atas Aset. Hal tersebut diperkuat oleh hasil penelitian yang dilakukan oleh (Abbas 2017) dan (Rahmah, Cipta, and Yudiaatmaja 2016) yang mengatakan bahwa bahwa Rasio Lancar berpengaruh positif terhadap Rasio Laba atas Aset. Hal tersebut menunjukkan bahwa kreditur akan mengetahui seberapa besar tingkat keamanan uang yang di investasikan pada perusahaan tersebut dengan melihat rasio lancarnya. Semakin baik rasio likuiditas ini maka keadaan perusahaan akan semakin likuid. Ini berarti perusahaan semakin mampu merespon kebutuhan sehari-harinya, sehingga tujuan utamanya untuk mendapatkan laba yang optimal dapat tercapai. Tentu hal tersebut akan berdampak pada profitabilitas perusahaan yang semakin meningkat.

Berdasarkan hasil uji statistik dalam tabel 6 terlihat bahwa Rasio Hutang terhadap Ekuitas mampu menjadi variabel mediasi antara Rasio Lancar terhadap Rasio Laba atas Aset. Hal tersebut dapat dibuktikan berdasakan nilai Z Score yang berada diatas 1.98 yaitu 1.99. dengan kata lain bahwa Rasio Hutang terhadap Ekuitas adalah suatu variabel yang dapat dijadikan suatu pilihan perusahaan untuk meningkatkan modal kerjanya agar kegiatan operasional perusahaan akan tetap terus berjalan sehingga perusahaan dapat meningkatkan produksi penjualannya dengan begitu pendapatan pun akan meningkat dengan pangsa pasar yang sudah pasti.

\section{Pengaruh Rasio Perputaran Piutang terhadap Rasio Laba atas Aset.}

Berdasarkan hasil uji persamaan model 1 seperti didalam Tabel 6 terlihat bahwa nilai coefficient variabel dari Rasio Perputaran Piutang memiliki pengaruh negatif sebesar -0.009 terhadap Rasio Laba atas Aset. Pengaruh Rasio Perputaran Piutang memiliki nilai siginifikan jika seseuai kriteria statistik karena didapatkan besaran nilainya yakni sebesar 0.009 lebih kecil dari 0.05, sehingga Hipotesa 2 dapat diterima. dengan demikian berarti, terdapat pengaruh dari variabel Rasio Perputaran Piutang terhadap Rasio Laba atas Aset perusahaan manufaktur subsektor Otomotif dan Komponen yang terdaftar di Bursa Efek Indonesia (BEI) dari tahun 20112018.

Menurut hasil penelitian yang dilakukan oleh hasil penelitian yang dilakukan oleh (Abbas and Pambudy 2019) yang menyatakan bahwa Rasio Peputaran Piutang Usaha berpengaruh negatif terhadap Rasio Laba Atas Aset. Hal tersebut menunjukkan bahwa semakin besar piutang yang tertanam diperusahaan lain akan berdampak pada menurunnya perputaran penerimaan kas perusahaan, sehingga perusahaan menjadi kekurangan modal dalam hal meningkatkan pengembalian asetnya. Namun berbeda dengan hasil penelitian 
yang dilakukan oleh (Suryadi, Taqwa, and Areva 2012) menyatakan bahwa Rasio Peputaran Piutang Usaha berpengaruh positif terhadap Rasio Laba Atas Aset. Hal tersebut mengartikan bahwa semakin tepat waktu pelanggan dalam pelunasan piutangnya dengan batas waktu yang dijanjikan atas penjualan yang telah diberikan, dengan kata lain bahwa perusahaan telah memanajemen piutang usahanya dengan baik sehingga mampu menagih penjualan sesuai dengan komitmen yang telah ditentukan dan sehingga terhindar dari resiko adanya piutang tak tertagih dari Pelanggan.

Berdasarkan hasil uji statistik dalam tabel 6 terlihat bahwa Rasio Hutang terhadap Ekuitas tidak mampu menjadi variabel mediasi antara Rasio Perputaran Piutang terhadap Rasio Laba atas Aset. Hal tersebut dapat dibuktikan berdasakan nilai Z Score yang berada dibawah 1.98 yaitu 1.79. dengan kata lain bahwa Rasio Hutang terhadap Ekuitas adalah suatu variabel yang tidak dapat dijadikan suatu pilihan perusahaan dalam meningkatkan penagihan piutang yang tertanam diperusahaan lain. Karena pada dasarnya Rasio Perputaran Piutang sangat dipengaruhi oleh tingkat kemampuan para manajemen diperusahaan tersebut dalam mengelola piutang usaha perusahaan dalam hal ini pemasukan kas.

\section{Pengaruh Rasio Perputaran Persediaan terhadap Rasio Laba atas Aset.}

Berdasarkan hasil uji persamaan model 1 seperti didalam Tabel 6 terlihat bahwa nilai coefficient variabel dari Rasio Perputaran Persediaan memiliki pengaruh positif sebesar 0.003 terhadap Rasio Laba atas Aset. Namun Rasio Perputaran Persediaan tidak memiliki nilai siginifikan jika sesuai kriteria statistik karena didapatkan besaran nilainya yakni sebesar 0.464 lebih besar dari 0.05, sehingga Hipotesa 3 tidak dapat diterima. dengan demikian berarti, terdapat pengaruh namun tidak signifikan dari variabel Rasio Perputaran Persediaan terhadap Rasio Laba atas Aset perusahaan manufaktur subsektor Otomotif dan Komponen yang terdaftar di Bursa Efek Indonesia (BEI) dari tahun 2011-2018.

vaiabel Perputaran Persediaan. menurut hasil penelitian yang dilakukan oleh (Rahmawati 2012) Inventory Turnover, and Debt to Equity Ratio toward the Return on Assets (A Case Study of Listed Food and Beverage Company on the Indonesia Stock Exchange Years of 2007-2009 dan (Suryadi, Taqwa, and Areva 2012) menyatakan bahwa Perputaran Persediaan berpengaruh positif terhadap Rasio Laba atas Aset. Hal ini mengartikan bahwa rata-rata perputaran persediaan pada perusahaan cukup tinggi, yang menunjukkan bahwa semakin efesien waktu yang dibutuhkan perusahaan dalam menggunakan persediaan, maka semakin hemat biaya yang harus dikorbankan oleh perusahaan dalam hal biaya produktivitasnya. Dengan kata lain semakin efesien biaya yang harus digunakan perusahaan, maka hal tersebut akan meningkatkan laba perusahaan menjadi naik. Namun berbeda dengan hasil penelitian yang dilakukan oleh (Abbas 2017) yang menyatakan bahwa Rasio Peputaran Persediaan berpengaruh negatif terhadap Rasio Laba Atas Aset. Hal tersebut berarti menunjukkan bahwa volume penjualan yang tinggi pada perusahaan tersebut jika tidak dimbangi dengan pengelolaan aset persediaan yang baik akan menurunkan tingkat keefisiensian serta keefektifan perusahaan saat persediaan yang tinggi, dimana hal ini juga akan diikuti oleh meningkatkannya biaya-biaya yang terjadi selama pengelolaan persediaan berlangsung sehingga akan menurunkan pendapatan perusahaan. Namun berbeda dengan hasil penelitian yang dilakukan oleh (Budiang, Pangemanan, and Gerungai 2017) yang 
menyatakan bahwa rasio perputaran persediaan tidak memiliki pengaruh terhadap Rasio Laba Atas Aset. Hal ini dikarenakan bahwa ketidakmampuan manajemen dalam memasarkan produk perusahaan sehingga barang yang siap dijual menjadi tertumpuk di gudang sehingga menyebabkan membengkaknya biaya-biaya yang seharusnya tidak menjadi tanggungan perusahaan maka hal tersebut akan menurunkan omset perusahaan dan Rasio Laba Atas Aset.

Berdasarkan hasil uji statistik dalam tabel 6 terlihat bahwa Rasio Hutang terhadap Ekuitas tidak mampu menjadi variabel mediasi antara rasio perputaran persediaan terhadap Rasio Laba atas Aset. Hal tersebut dapat dibuktikan berdasakan nilai Z Score yang berada dibawah 1.98 yaitu -0.71 . dengan kata lain bahwa Rasio Hutang terhadap Ekuitas adalah suatu variabel yang tidak dapat dijadikan suatu pilihan perusahaan dalam mempengaruhi dinamika keberhasilan akan penjualan produk perusahaan. justru jika manajemen tetap memaksa untuk tetap melakukan pinjaman dengan situasi perusahaan yang sedang mengalami kegagalan produk dalam bersaing dipasar maka dapat dipastikan perusahaan tersebut akan mengalami financial distress sehingga akan berpengaruh tentang going concern perusahaan tersebut.

\section{Pengaruh Rasio Perputaran Total Aset terhadap Rasio Laba atas Aset.}

Berdasarkan hasil uji persamaan model 1 seperti didalam Tabel 6 terlihat bahwa nilai coefficient variabel dari Rasio Perputaran Total Aset memiliki pengaruh positif sebesar 0.073 terhadap Rasio Laba atas Aset. Pengaruh Rasio Perputaran Total Aset memiliki nilai siginifikan jika sesuai kriteria statistik karena didapatkan besaran nilainya yakni sebesar 0.001 lebih kecil dari 0.05, sehingga Hipotesa 4 dapat diterima. dengan demikian berarti, terdapat pengaruh dari variabel Rasio Perputaran Total Aset terhadap Rasio Laba atas Aset perusahaan manufaktur subsektor Otomotif dan Komponen yang terdaftar di Bursa Efek Indonesia (BEI) dari tahun 20112018.

Lalu dugaan lainnya, Variabel Rasio Perputaran Total Aset. Menurut hasil penelitian yang dilakukan (Mahardhika and Marbun 2016), (Ambarwati, Yuniarta, and Sinarwati 2015), dan (Rahmah, Cipta, and Yudiaatmaja 2016) dan (Abbas 2017) menyatakan bahwa Total Asset Turnover berpengaruh positif terhadap Return On Assets. Hal tersebut berarti menunjukkan bahwa suatu perputaran Aset yang terjadi diperusahaan memiliki pengaruh yang signifikan dalam tingkat pengembalian aset perusahaan. Karena tingkat perputaran aset dapat meningkatkan penjualan pada perusahaan tersebut. Kondisi ini menunjukkan bahwa semakin tinggi nilai perputaran aset maka akan semakin besar tingkat penjualan, sehingga laba yang diterima perusahaan pun meningkat.

Dalam uji statistik juga menjelaskan bahwa Rasio Hutang terhadap Ekuitas tidak mampu memediasi Rasio Perputaran Total Aset terhadap Rasio Laba atas Aset. Hal ini terlihat dalam nilai Z Score dibawah 1.98 yaitu -1.87. dengan kata lain bahwa Rasio Hutang terhadap Ekuitas adalah suatu variabel yang tidak dapat dijadikan suatu pilihan perusahaan Karena dengan adanya penambahan pinjaman dari bank ataupun investasi dari investor belum tentu bisa menjamin perusahaan untuk meningkatkan perputaran total aset demi memperbesar laba perusahaan. Karena timbulnya biaya modal yang wajib perusahaan berikan baik kepada bank berupa bunga bank dan kepada investor berupa deviden. Sehingga manajamen perusahaan 
akan dihadapakan oleh permasalahan baru yang mungkin saja akan lebih mengarah ke financial distress. Jika hal tersebut terjadi dan tetap dipaksakan oleh manajemen maka tidak menutup kemungkinan manajemen perusahaan akan melakukan manajemen laba agar tetap bisa terus exist dan selalu dapat kepercayaan dari pihak - pihak pemilik dana baik itu bank maupun investor.

\section{Pengaruh Rasio Hutang terhadap Ekuitas terhadap Rasio Laba atas Aset.}

Berdasarkan hasil uji persamaan model 1 seperti didalam Tabel 6 terlihat bahwa nilai coefficient variabel dari Rasio Hutang terhadap Ekuitas memiliki pengaruh negatif sebesar 0.020 terhadap Rasio Laba atas Aset. Pengaruh Rasio Hutang terhadap Ekuitas memiliki nilai siginifikan jika sesuai kriteria statistik karena didapatkan besaran nilainya yakni sebesar 0.022 lebih kecil dari 0.05, sehingga Hipotesa 5 dapat diterima. dengan demikian berarti, terdapat pengaruh dari variabel Rasio Hutang terhadap Ekuitas terhadap Rasio Laba atas Aset perusahaan manufaktur subsektor Otomotif dan Komponen yang terdaftar di Bursa Efek Indonesia (BEI) dari tahun 2011-2018.

Menurut hasil penelitian yang dilakukan oleh (Rahmawati 2012)Inventory Turnover, and Debt to Equity Ratio toward the Return on Assets (A Case Study of Listed Food and Beverage Company on the Indonesia Stock Exchange Years of 2007-2009, dan (Rahmah, Cipta, and Yudiaatmaja 2016) didalam hasil penelitian mereka menyatakan bahwa Rasio Hutang terhadap Ekuitas berpengaruh Negatif terhadap Laba atas Aset. Hal tersebut mengartikan bahwa adanya penambahan pinjaman dari bank dan investasi dari investor dapat menurunkan laba perusahaan. Karena perusahaan dibebankan oleh biaya modal (cost of capital) seperti Bunga Bank atau Deviden. Penjelasan tersebut didasari berdasarkan dari sifat asli pencatatan dan pengakuan pendanaan dalam pembukuan akuntansi, adanya penambahan pinjaman dan investasi maka akan dicatat sisi kredit dalam kelompok liabilitas dan ekuitas, begitupula jika terjadi pembayaran akan dicatat sisi debit dalam kelompok liabilitas dan ekuitas. Namun, hasil penelitian tersebut bertolak belakang dengan dengan hasil penelitian yang dilakukan oleh (Mahardhika and Marbun 2016) menyatakan bahwa Rasio Hutang terhadap Ekuitas positif terhadap Rasio Laba atas Aset. Hal ini mengartikan bahwa semakin besar tingkat pinjaman yang dimiliki oleh perusahaan, sangat mempengaruhi tingkat kemampuan perusahaan dalam memperoleh labanya.

\section{Pengaruh Rasio Lancar terhadap Rasio Hutang terhadap Ekuitas.}

Berdasarkan hasil uji persamaan model 1 seperti didalam Tabel 6 terlihat bahwa nilai coefficient variabel dari Rasio Lancar memiliki pengaruh negatif sebesar 0.317 terhadap Rasio Hutang terhadap Ekuitas. Pengaruh Rasio Lancar memiliki nilai siginifikan jika sesuai kriteria statistik karena didapatkan besaran nilainya yakni sebesar 0.000 lebih kecil dari 0.05, sehingga Hipotesa 6 dapat diterima. dengan demikian berarti, terdapat pengaruh dari variabel Rasio Lancar terhadap Rasio Hutang terhadap Ekuitas perusahaan manufaktur subsektor Otomotif dan Komponen yang terdaftar di Bursa Efek Indonesia (BEI) dari tahun 2011-2018.

Berdasarkan hasil penelitian yang dilakukan (Hantono 2015) dalam penelitiannya menyatakan bahwa Rasio Lancar berpengaruh negative terhadap Debt to Equity. Hal ini mendefinisikan bahwa semakin rendah tingkat likuiditas suatu hutang lancar yang dimiliki oleh perusahaan, maka akan menurunkan manajemen 
untuk mengajukan pinjaman modal ke bank. sehingga hal tersebut mempengaruhi manajemen dalam meningkatkan kemampuan perusahaan dalam memperoleh untungnya.

\section{Pengaruh Rasio Perputaran Piutang Usaha terhadap Rasio Hutang terhadap Ekuitas}

Berdasarkan hasil uji persamaan model 1 seperti didalam Tabel 6 terlihat bahwa nilai coefficient variabel dari Rasio Perputaran Piutang Usaha memiliki pengaruh negatif sebesar 0.025 terhadap Rasio Hutang terhadap Ekuitas. Pengaruh Rasio Perputaran Piutang Usaha tidak memiliki nilai siginifikan jika sesuai kriteria statistik karena didapatkan besaran nilainya yakni sebesar 0.524 lebih besar dari 0.05, sehingga Hipotesa 7 tidak dapat diterima. dengan demikian berarti, tidak terdapat pengaruh dari variabel Rasio Perputaran Piutang Usaha terhadap Rasio Hutang terhadap Ekuitas perusahaan manufaktur subsektor Otomotif dan Komponen yang terdaftar di Bursa Efek Indonesia (BEI) dari tahun 2011-2018.

Dapat diartikan bahwa tidak adanya keterkaitan antara Rasio perputaran piutang dengan Rasio Hutang terhadap ekuitas. Hal tersebut dikarenakan jika Rasio perputaran piutang berbicara tentang pengelolaan piutang yang tertanam diperusahaan lain, lalu Rasio Hutang terhadap ekuitas berbicara tentang seberapa besar ekuitas yang dimiliki oleh perusahaan dalam menutupi hutang jangka panjangnya. Dengan kata lain jika pun perusahaan meningkatkan sumber pendanaan dari pihak ketiga, hal tersebut tentu tidak begitu saja akan meningkatan penjualan perusahaan yang didasari oleh accrual basis atau bahkan membuat penagihan piutang yang dilakukan menjadi lebih cepat dan lancar dengan tingkat pengembalian pinjaman rata-rata 1-2 hari saja.

\section{Pengaruh Rasio Perputaran Persediaan terhadap Rasio Hutang terhadap Ekuitas}

Berdasarkan hasil uji persamaan model 1 seperti didalam Tabel 6 terlihat bahwa nilai coefficient variabel dari Rasio Perputaran Persediaan memiliki pengaruh negatif sebesar 0.028 terhadap Rasio Hutang terhadap Ekuitas. Pengaruh Rasio Perputaran Persediaan memiliki nilai siginifikan jika sesuai kriteria statistik karena didapatkan besaran nilainya yakni sebesar 0.528 lebih besar dari 0.05, sehingga Hipotesa 8 tidak dapat diterima. dengan demikian berarti, tidak terdapat pengaruh dari variabel Rasio Perputaran Persediaan terhadap Rasio Hutang terhadap Ekuitas perusahaan manufaktur subsektor Otomotif dan Komponen yang terdaftar di Bursa Efek Indonesia (BEI) dari tahun 2011-2018.

Dapat diartikan bahwa tidak adanya keterkaitan antara Rasio Perputaran Persediaan dengan Rasio Hutang terhadap ekuitas. Hal tersebut dikarenakan jika Rasio Perputaran Persediaan berbicara tentang kemampuan seberapa banyak tingkat persediaan perusahaan dapat terjual dipasaran, lalu Rasio Hutang terhadap ekuitas berbicara tentang seberapa besar ekuitas yang dimiliki oleh perusahaan dalam menutupi hutang jangka panjangnya. Dengan kata lain jika manajemen perusahaan telah berhasil menjual produknya tentulah hal tersebut tidak ditentukan berdasarkan oleh besar atau kecilnya suatu pinjaman yang yang dimiliki oleh perusahaan. Tentu saja hal tersebut dikarenakan dari sifat alami produk yang dijual mengingat sampel yang dijadikan objek dalam penelitian ini adalah perusahaan manufaktur subsektor Otomotif dan Komponen. Tentu saja jenis perusahaan ini sudah memiliki pangsa pasar sendiri untuk penjualannya. 


\section{Pengaruh Rasio Perputaran Total Aset terhadap Rasio Hutang terhadap Ekuitas}

Berdasarkan hasil uji persamaan model 1 seperti didalam Tabel 6 terlihat bahwa nilai coefficient variabel dari Rasio Perputaran Total Aset memiliki pengaruh negatif sebesar 0.231 terhadap Rasio Hutang terhadap Ekuitas. Pengaruh Rasio Perputaran Total Aset memiliki nilai tidak siginifikan jika sesuai kriteria statistik karena didapatkan besaran nilainya yakni sebesar 0.359 lebih besar dari 0.05, sehingga Hipotesa 9 tidak dapat diterima. dengan demikian berarti, tidak terdapat pengaruh dari variabel Rasio Perputaran Total Aset terhadap Rasio Hutang terhadap Ekuitas perusahaan manufaktur subsektor Otomotif dan Komponen yang terdaftar di Bursa Efek Indonesia (BEI) dari tahun 2011-2018.

Dapat diartikan bahwa tidak adanya keterkaitan antara Rasio Perputaran Total Aset dengan Rasio Hutang terhadap ekuitas. Hal tersebut dikarenakan jika Rasio Perputaran Total Aset berbicara tentang kemampuan perusahaan dalam memaksimalkan penggunaan total aset dalam rangka menghasilkan penjualan dengan membandingkan penjualan bersih dengan rata-rata total aset, lalu Rasio Hutang terhadap ekuitas berbicara tentang seberapa besar ekuitas yang dimiliki oleh perusahaan dalam menutupi hutang jangka panjangnya. Besar kecilnya suatu pinjaman yang dimiliki oleh perusahaan tidak semata-mata akan mempengaruhi manajemen untuk memaksimalkan penggunaan sumber daya asset yang ada diperusahaan.

\section{KESIMPULAN}

Berdasarkan pembahasan tentang analisis regresi serta penjelasan yang telah diuraikan, maka didapatkan beberapa suatu kesimpulan. Pertama, bahwa variabel Rasio Laba atas Aset dapat dijelaskan oleh variabel Rasio Lancar, Rasio Perputaran Piutang Usaha, Rasio Perputaran Persediaan, Rasio Perputaran Total Aset dan Rasio Hutang terhadap Ekuitas sebesar 19.9\%, sementara 80.10\% dijelaskan oleh variabel-variabel lain yang tidak berada dalam penelitian. Kedua, setelah melalui pengolahan data didapatkan suatu hasil atas pengujian yang telah dilakukan. Dikatakan bahwa dapat diketahui jika Rasio Lancar dan Rasio Perputaran Total Aset memiliki pengaruh positif signifikan terhadap Rasio Laba atas Aset. Lalu, variabel Rasio Perputaran Total Aset dan Rasio Hutang terhadap Ekuitas memiliki pengaruh negatif signifikan terhadap Rasio Laba atas Aset. Sedangkan, hasil perhitungan analisis jalur serta Sobel Test didapatkan kesimpulan bahwa Rasio Hutang terhadap Ekuitas hanya memediasi pengaruh Rasio Lancar terhadap Rasio Laba atas Aset.

\section{DAFTAR PUSTAKA}

Abbas, Dirvi. 2017. “Pengaruh Current Ratio, Account Receivable Turnover, Inventory Turnover, Total Asset Turnover Dan Debt To Equity Terhadap Return On Asset (Pada Perusahaan Manufaktur Sub Sektor Otomotif Dan Komponen Yang Terdaftar Di Bursa Efek Indonesia Pada Tahun 2011-2." Competitive 2(1): 55-72. Http://Jurnal.Umt.Ac.Id/Index.Php/Competitive/Issue/View/117. Abbas, Dirvi, And Januar Pambudy. 2019. “Pengaruh Rasio Aktivitas Terhadap Profitabilitas (Pada Perusahaan Pertambangan Yang Terdaftar Di Bursa Efek Indonesia Periode 2010-2018)." Balance 
Vocation Accounting Journal 3(1): 50-66. Http://Jurnal.Umt.Ac.Id/Index.Php/Bvaj/Article/View/1942. Ambarwati, Novi Sagita, Gede Adi Yuniarta, And Ni Kadek Sinarwati. 2015. “Pengaruh Modal

Kerja, Likuiditas, Aktivitas Dan Ukuran Perusahaan Terhadap Profitabilitas Pada Perusahaan Manufaktur Yang Terdaftar Di Bursa Efek Indonesia." E-Journal S1 Ak Universitas Pendidikan Ganesha 3(1): 11.

Basuki, Agus Tri. 2015. “Regresi Dalam Penelitian Ekonomi Dan Bisnis.” Yogyakarta: Danisa Media. Brigham, Eugene F, And Louis C Gapenski. 1993. Intermediate Financial Management. Fort Worth: The Dryden Press.

Budiang, F T, S S Pangemanan, And N Y T Gerungai. 2017. 5 Jurnal Emba The Effect Of Total Asset Turnover, Receivable Turnover And Inventory Turnover Towards Roa Of Retail Trade Sub-Sector Listed On The Bei.

Ghozali, Imam. 2013. Badan Penerbit Universitas Diponogoro Aplikasi Multivariate Dengan Program Spss, Edisi 3.

Hantono. 2015. “Pengaruh Current Ratio Dan Debt To Equity Ratio Terhadap Profitabilitas Pada Perusahaan Manufaktur Sektor Logam Dan Sejenisnya Yang Terdaftar Di Bursa Efek Indonesia Periode 2009 - 2013." Jurnal Wira Ekonomi Mikroskil 5(April): 1.

Hayes, A.F., And K.J. Preacher. 2004. “Spss And Sas Procedures For Estimating Indirect Effecs In Simple Mediation Model." Behavior Research Methods, Instruments \& Computers 36: 717-31.

Listiyowati, Indarti. 2018. “Listiyowati.” Analisis Pengaruh Good Corporate Governance Terhadap Nilai Perusahaan Dengan Profitabilitas Sebagai Variabel Intervening 4(18): 1-16.

Mahardhika, Pa, And Dohar Marbun. 2016. “Pengaruh Current Ratio Dan Debt To Equity Ratio Terhadap Return On Assets." Widyakala Journal 3: 23.

Nasution, D. D. 2019. “Industri Komponen Otomotif Ri Terhambat Masalah Bahan Baku.” Https:// Republika.Co.Id/Berita/Pw6efc383/Industri-Komponen-Otomotif-Ri-Terhambat-Masalah-BahanBaku.

Priyatno, Duwi. 2012. Cara Kilat Belajar Analisis Data Dengan Spss 20. Yogyakarta: Andi. Https://Opac. Perpusnas.Go.Id/Detailopac.Aspx?Id=728498\#.

Rahmah, Amrita Maulidia, Wayan Cipta, And Fridayana Yudiaatmaja. 2016. “Otomotif Yang Terdaftar

Di Bursa Efek Indonesia Periode 2012-2014." E-Journal Bisma Universitas Pendidikan Ganesha 4(1).

Rahmawati, F. L. 2012. “Pengaruh Current Ratio, Inventory Turnover, Dan Debt To Equity Ratio Terhadap Return On Assets (Studi Pada Perusahaan Food And Beverage Yang Listing Di Bursa Efek Indonesia Tahun 2007-2009)." Fe.Um.Ac.Id 0(0): 13.

Sugiyono, Prof. Dr. 2017. Statistik Untuk Penelitian. 10th Ed. Bandung: Cv Alfabeta. Http://Staffnew.Uny. Ac.Id/Upload/131808329/Penelitian/17b_Editor+Buku+Statistik.Pdf.

Suryadi, Salma Taqwa, And Desi Areva. 2012. “Pengaruh Perputaran Modal Kerja Terhadap Return

On Asset Perusahaan (Studi Kasus Pada Perusahaan Dagang Masri M. Syariah Cabang Padang Periode 2008-2012)." Media.Neliti.Com: 1-9. 